\title{
Randomized comparative study of oral misoprostol with intravenous methyl ergometrine in prevention of postpartum haemorrhage in cases high risk for postpartum haemorrhage
}

\author{
Aisha Humera*, Sudha Biradar Kerure \\ Department of Obstetrics \& Gynaecology, ESIC Medical College, Kalaburagi, Karnataka, India \\ Received: 17 January 2016 \\ Revised: 17 February 2016 \\ Accepted: 22 February 2016 \\ *Correspondence: \\ Dr. Aisha Humera, \\ E-mail: dr_aisha210@yahoo.com \\ Copyright: () the author(s), publisher and licensee Medip Academy. This is an open-access article distributed under \\ the terms of the Creative Commons Attribution Non-Commercial License, which permits unrestricted non-commercial \\ use, distribution, and reproduction in any medium, provided the original work is properly cited.
}

\begin{abstract}
Background: Postpartum haemorrhage accounts for $30 \%$ of maternal deaths in rural areas. Active management of 3rd stage of labour with prophylactic uterotonics reduces the PPH up to $40 \%$. The objective of our study was to compare the efficacy and side effects of Oral Misoprostol $(600 \mu \mathrm{g})$ and Intravenous Methyl ergometrine $(0.2 \mathrm{mg})$ in the prevention of PPH in cases high risk for PPH.

Methods: One hundred high risk pregnant women at term in labour were included in the study and were randomly

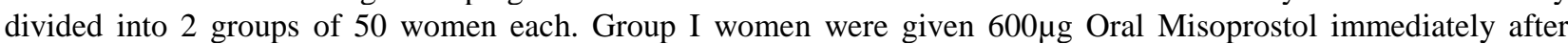
delivery of fetus and group II were given intravenous methylergometrine $0.2 \mathrm{mg}$ after delivery of anterior shoulder of fetus. The main outcome measures of third stage of labour studied were: duration; blood loss by volume, need for additional oxytocics, blood transfusion \& side effects.

Results: Demographic and clinical variables of both groups were comparable. There were no significant differences in main outcome measures between both the groups. Shivering was the most common side effect noted in misoprostol group.

Conclusions: In high risk women oral misoprostol appears to be as effective as intravenous methylergometrine in minimizing $3^{\text {rd }}$ stage blood loss. Misoprostol has greatest potential for use in 3rd stage of labour especially in developing countries.
\end{abstract}

Keywords: Postpartum haemorrhage, Misoprostol, Methyl ergometrine

\section{INTRODUCTION}

Pregnancy and childbirth involves significant health risks, even to women with no pre-existing health problem. WHO estimated that 5,29,000 women died from complications of pregnancy and childbirth. ${ }^{1}$ Most of these deaths occur in developing countries, often because women lack access to life saving care. A woman living in a developing country is likely to receive antenatal care but she is less likely to have skilled care during labour, childbirth or the postpartum period. Severe bleeding or hemorrhage is the single most important cause of maternal death worldwide, half of which occurs within $24 \mathrm{hrs}$ of delivery. At least one quarter of all maternal deaths is due to hemorrhage, the proportion ranges from less than 10 percent to nearly 60 percent in various countries. Maternal mortality rate in India is estimated to be 301 per 100,000 live births out of which $30 \%$ of deaths are due to postpartum haemorrhage. ${ }^{1} 80 \%$ of Indian population resides in rural areas and about $50-60 \%$ of the deliveries are home deliveries, especially in resource poor set-ups where no proper medical facilities for blood transfusion, transportation are available. ${ }^{2}$ 
Moreover in such areas regular antenatal check-ups and recognition of high risk caesarean are hardly done.

The commonest cause of postpartum hemorrhage is uterine atony. By various studies conducted it has been proved that prevention of PPH can be achieved by active management of third stage of labour in almost $40 \%$ of cases. $^{3,11}$

Till today commonly used oxytocic drugs for prevention of PPH are oxytocin, ergometrine or combination of both but, unfortunately they are unstable at high ambient temperature, expensive, need refrigeration for storage and transport, need sterile needle and syringe for parenteral administration and trained personnel for administration.

Hence current oxytocic drugs are far from ideal, particularly for routine use in developing countries, in resource poor set-up and hence, there is a need for an effective uterotonic drug that can be administered orally and which does not require special storage condition.

Misoprostol, a synthetic prostaglandin E1 analogue, which was basically used for the treatment of gastric ulcers and has action over the uterine myometrium causing the uterus to contract and thus can be used for prevention of postpartum bleeding. ${ }^{2}$ Misoprostol has a range of potential benefits including rapid absorption, ease of administration (oral, rectal, sublingual) which does not require any trained personnel and can be administered by traditional birth attendants, cost effectiveness and no special condition for the storage and transport, has a shelf-life of several years and thus it proves to be a suitable uterotonic agent for use in the prophylactic management of third stage of labour especially in resource-poor set-up in developing countries like ours. 6,9

So, the present study is an attempt to assess the effect of oral misoprostol on $3^{\text {rd }}$ stage of labour in comparison with standard methergine regimen.

\section{METHODS}

This study was conducted in the Department of Obstetrics and Gynaecology at Yenepoya Medical College Hospital, Mangalore during the period of two years from November 2007 to October 2009.

\section{Inclusion criteria}

- All parous women in labour.

- Multiple fetal gestation.

- Induced or augmented labour.

- Moderate to severe anaemia not in failure.

- Hydramnios.

\section{Exclusion criteria}

- Pre-eclampsia and eclampsia
- Previous caesarean section

- Previous h/o retained placenta

- Antepartum hemorrhage

- Coagulation abnormalities

- Pregnancy complicated with medical disorders like cardiac diseases, diabetes, hypertension and epilepsy.

\section{Methods of collection of data}

After a detailed history, general and obstetric examination and routine investigation, 100 patients who fulfilled the selection criteria were included in the study. Institutional ethical committee approved the study protocol.

A total of 100 cases were studied with 50 cases in each group. An informed consent was taken from the patient in both the groups. In the third stage of labour, immediately after the delivery of the baby, the cord was clamped and cut. The women were given either intravenous Methyl ergometrine $0.2 \mathrm{mg}$ at the delivery of anterior shoulder of foetus or Oral misoprostol $600 \mu \mathrm{g}$ (3 tablets) immediately after the delivery of foetus randomly.

The placenta was delivered by controlled cord traction. Placenta and membranes were examined for completeness after expulsion. The duration of third stage of labour was noted in both the groups. The blood loss during the third stage of labour and the immediate postpartum period (1 hour after delivery) was measured. After delivery of the baby amniotic fluid was allowed to drain away (if present) and amniotic fluid soaked bed linen covered with dry disposable linen saver, corrugated rubber sheet placed under buttocks, sterile kidney tray placed at the vulva was used to collect blood loss over next 1 hour. Collected blood was measured using a measuring jar, blood clots weighed separately $(1 \mathrm{gm}=1 \mathrm{ml})$. Blood soaked swabs were weighed, the known dry weight subtracted and the calculated volume added to that of the blood volume of measuring jar. If intravenous oxytocin was used during the second stage of labour, it was stopped immediately after delivery.

Postpartum hemorrhage in the present study is defined as blood loss $\geq 500 \mathrm{ml}$ in $1^{\text {st }}$ hour after delivery. Once the diagnosis of postpartum hemorrhage was made, the patients were managed as per the needs by giving additional oxytocics drugs (IV oxytocin infusion or injection prostodin).

Patients were observed for 2 hours following delivery for vital signs and bleeding per vagina. The occurrence of side effects like nausea, vomiting, shivering, fever, diarrhea etc. within first 2 hours of delivery were recorded in the proforma designed for the study.

The study was computed by using p-value and chi-square test. $\mathrm{p}$ value $<0.001$ was considered significant. 


\section{RESULTS}

Out of the 100 patients studied in both the groups' majority of the patients was registered $58 \%$ v/s $76 \%$ with the difference between them being statistically not significant (Table 1). The distribution of patients according to high risk factor was similar in both groups. Maximum number of patients was multiparous in both the groups (Table 1). The episiotomy required in both the groups was comparable (Table 3 ).

Table 1: Distribution of cases according to registration and high risk factors.

\begin{tabular}{|c|c|c|c|}
\hline & $\begin{array}{l}\text { Misoprosto } \\
\text { l } \\
(\mathrm{n}=50)\end{array}$ & $\begin{array}{l}\text { Methyl } \\
\text { ergometrine } \\
(\mathrm{n}=50)\end{array}$ & P-value \\
\hline \multicolumn{3}{|l|}{ Registration } & \multirow{3}{*}{$\mathrm{P}>0.05$} \\
\hline Registered & $29(58.0 \%)$ & $38(76.0 \%)$ & \\
\hline Unregistered & $21(42.0 \%)$ & $12(24.0 \%)$ & \\
\hline \multicolumn{3}{|l|}{ High risk factors } & \multirow{11}{*}{$\mathrm{P}=0.47$} \\
\hline Hydramnios & $1(2 \%)$ & $2(4 \%)$ & \\
\hline Induced labour & $7(14 \%)$ & $7(14 \%)$ & \\
\hline $\begin{array}{l}\text { Prolonged } \\
\text { labour }\end{array}$ & $00 \%$ & $1(2.0 \%)$ & \\
\hline $\begin{array}{l}\text { Anaemia, } \\
\text { augmented } \\
\text { labour }\end{array}$ & $00 \%$ & $2(4 \%)$ & \\
\hline $\begin{array}{l}\text { Induced labour, } \\
\text { Prolonged labour }\end{array}$ & $1(2 \%)$ & $1(2 \%)$ & \\
\hline Multiparity & $23(46 \%)$ & $28(56 \%)$ & \\
\hline $\begin{array}{l}\text { Multiparity, } \\
\text { Anaemia }\end{array}$ & $9(18 \%)$ & $3(6 \%)$ & \\
\hline $\begin{array}{l}\text { Multiparity } \\
\text { Augmented } \\
\text { labour } \\
\text { Multiparity }\end{array}$ & $3(6 \%)$ & $2(4 \%)$ & \\
\hline $\begin{array}{l}\text { Hydramnios } \\
\text { Multiparity }\end{array}$ & $1(2 \%)$ & $2(4 \%)$ & \\
\hline Induced labour & $5(10 \%)$ & $2(4 \%)$ & \\
\hline
\end{tabular}

Duration of $3^{\text {rd }}$ stage of labour was less than 6 minutes in maximum number of patients in both the groups. The duration was 10 minutes or more in $6 \%$ of cases in methyl ergometrine group compared to $8 \%$ of cases in misoprostol group. The mean duration of $3^{\text {rd }}$ stage of labour in both the groups were comparable statistically (Table 2). In both the groups' blood loss in most of the cases was up to $200 \mathrm{ml}$. $4 \%$ in misoprostol group and $2 \%$ in methyl ergometrine had blood loss more than $500 \mathrm{ml}$. None of the cases in both groups have blood loss more than $1000 \mathrm{ml}$. The average third stage blood loss is slightly more in misoprostol group as compared to methyl ergometrine group. But the difference between two groups was statistically not significant (Table 3 ). There were 2 cases of postpartum hemorrhage in Misoprostol group and 1 case in Methyl ergometrine group. There was no case of retained placenta noted in either of group (Table 4).
Table 2: Distribution based on duration and mean duration of 3rd stage of labour.

\begin{tabular}{|c|c|c|c|}
\hline & $\begin{array}{l}\text { Misoprostol } \\
(n=50)\end{array}$ & $\begin{array}{l}\text { Methyl } \\
\text { ergometrine } \\
(n=50)\end{array}$ & $\begin{array}{l}\text { P- } \\
\text { value }\end{array}$ \\
\hline $\begin{array}{l}\text { Duration } \\
\text { (mins) } \\
<6 \\
6-7 \\
8-9 \\
\geq 10\end{array}$ & $\begin{array}{l}28(56 \%) \\
10(20 \%) \\
8(16 \%) \\
4(8 \%)\end{array}$ & $\begin{array}{l}29(58 \%) \\
8(16 \%) \\
10(20 \%) \\
3(6 \%)\end{array}$ & $\mathrm{P}=0.85$ \\
\hline $\begin{array}{l}\text { Mean } \\
\text { Duration of } \\
3^{\text {rd }} \text { stage of } \\
\text { labour }\end{array}$ & $6.25 \pm 1.87$ & $6.28 \pm 1.70$ & $\mathrm{P}=0.93$ \\
\hline
\end{tabular}

Table 3: Distribution of blood loss, mean blood loss and episiotomy.

\begin{tabular}{|llll|}
\hline & $\begin{array}{l}\text { Misoprostol } \\
(\mathrm{n}=50)\end{array}$ & $\begin{array}{l}\text { Methyl } \\
\text { ergometrine } \\
(\mathrm{n}=50)\end{array}$ & P-value \\
\hline $\begin{array}{l}\text { Blood loss } \\
(\mathrm{ml})\end{array}$ & & & \\
$\leq 100$ & $4(8 \%)$ & $10(20 \%)$ & \\
$101-200$ & $34(68 \%)$ & $30(60 \%)$ & \\
$201-300$ & $7(14 \%)$ & $7(14 \%)$ & \\
$301-400$ & $3(6 \%)$ & $2(4 \%)$ & $\mathrm{P}>0.05$ \\
$401-500$ & $00 \%$ & $00 \%$ & \\
$>500$ & $2(4 \%)$ & $1(2 \%)$ & \\
$>1000$ & $00 \%$ & $00 \%$ & \\
\hline $\begin{array}{l}\text { Mean blood } \\
\text { loss(ml) }\end{array}$ & $195.10 \pm 94.25$ & $172.80 \pm 79.65$ & $\mathrm{P}=0.204$ \\
Episiotomy & & & \\
Yes & $10(20 \%)$ & $13(26 \%)$ & \\
No & $40(80 \%)$ & $37(74 \%)$ & $\mathrm{P}=0.47$ \\
\hline
\end{tabular}

Table 4: Comparison of postpartum complications and need for additional oxytocics.

\begin{tabular}{|c|c|c|c|}
\hline & $\begin{array}{l}\text { Misoprostol } \\
(\mathrm{n}=50)\end{array}$ & $\begin{array}{l}\text { Methyl } \\
\text { ergometrine } \\
(\mathrm{n}=50)\end{array}$ & P-value \\
\hline \multicolumn{4}{|c|}{ Postpartum complications } \\
\hline $\begin{array}{l}\text { Postpartum } \\
\text { Haemorrhage }\end{array}$ & $2(4 \%)$ & $1(2 \%)$ & \multirow[t]{2}{*}{$\mathrm{P}=0.58$} \\
\hline $\begin{array}{l}\text { Retained } \\
\text { placenta }\end{array}$ & $00 \%$ & $00 \%$ & \\
\hline \multicolumn{4}{|c|}{ Additional oxytocics } \\
\hline $\begin{array}{l}\text { I.V oxytocin } \\
\text { Infusion }\end{array}$ & $00 \%$ & $00 \%$ & \multirow[t]{2}{*}{$\mathrm{P}=0.585$} \\
\hline $\begin{array}{l}\text { Injection } \\
\text { prostodin }\end{array}$ & $2(4 \%)$ & $1(2 \%)$ & \\
\hline
\end{tabular}

Shivering was most common side effects noted in the misoprostol $38 \% \mathrm{v} / \mathrm{s} 8 \%$ whereas nausea was most common side effect noted in methylergometrine group $18 \% \mathrm{v} / \mathrm{s} 6 \%$ and the difference between the two groups was statistically significant (Table 5). 
Table 5: Side effects.

\begin{tabular}{|ll|l|}
\hline Side effects & $\begin{array}{l}\text { Misoprostol } \\
(\mathbf{n = 5 0 )}\end{array}$ & $\begin{array}{l}\text { Methyl } \\
\text { ergometrine } \\
(\mathbf{n = 5 0 )}\end{array}$ \\
\hline Nausea & $3(6.0 \%)$ & $9(18.0 \%)$ \\
\hline Vomiting & $2(4.0 \%)$ & $4(8.0 \%)$ \\
\hline Diarrhoea & 00 & 00 \\
\hline Shivering & $19(38.0 \%)$ & $4(8.0 \%)$ \\
\hline Pyrexia & $2(4.0 \%)$ & 00 \\
\hline Headache & 00 & 00 \\
\hline $\begin{array}{l}\text { Increase in } \\
\text { diastolic } \\
\text { blood pressure }\end{array}$ & 00 & $2(4.0 \%)$ \\
\hline
\end{tabular}

$\mathrm{P}=0.013$

\section{DISCUSSION}

Misoprostol is a prostaglandin $\mathrm{E}_{1}$ analogue, which has been shown to have myometrial stimulating property which can be administered orally and is rapidly absorbed, stable at room temperature, has low cost. ${ }^{6,9}$ In high risk cases where PPH can be anticipated, use of misoprostol can help in preventing PPH even in the hands of trained birth attendants or dias due to its simplicity of administration and manageable side-effects. Its use in $3^{\text {rd }}$ stage of labour was first suggested by El-Refaey $\mathrm{H}^{4}$ Amant et al conducted the study comparing efficacy and side-effects of Injection methyl ergometrine $0.2 \mathrm{mg}$ intravenously with misoprostol $600 \mu \mathrm{g}$ given orally for prevention of postpartum haemorrhage. ${ }^{7}$ Therefore, the present study was undertaken to evaluate the efficacy of oral misoprostol in the active management of $3^{\text {rd }}$ stage of labour and compare it with injection methylergometrine used intravenously in high risk women anticipating full term vaginal delivery.

The demographic variables of both the groups were comparable in relation to registration $58 \% \mathrm{v} / \mathrm{s} 76 \%$ registered cases (Table 1). Since the study was focused on high risk cases, in both the groups' majority of cases were multiparous (Table 1). Both the groups are comparable so far as episiotomy $20 \% \mathrm{v} / \mathrm{s} \quad 26 \%$ is concerned (Table 3).

In the present study, 92\% cases in misoprostol and $94 \%$ cases in methyl ergometrine group had third stage less than 10 mins. The mean duration of $3^{\text {rd }}$ stage was $6.25 \pm 1.87$ minutes in misoprostol group compared to $6.28 \pm 1.70$ minutes in methylergometrine group. The difference was not significant statistically (Table 2). Our study is in accordance with study conducted by Refaey et al in comparison to duration of third stage of labour in Misoprostol v/s standard oxytocics i.e $6.3 \mathrm{v} / \mathrm{s} 6.4$ mins. $^{10}$

In both the groups majority of women had blood loss up to $200 \mathrm{ml}$ i.e., $68 \%$ and $60 \%$ in misoprostol group and methyl ergometrine group respectively. The mean blood loss in third stage of labour was comparable in both groups in our study $195.10 \pm 94.25 \mathrm{v} / \mathrm{s} \quad 172.80 \pm 79.65$. (Table 3). In comparison to studies conducted by H. EL. Refaey et al i.e 256 v/s 251 and Walraven $\mathrm{G}$ et al i.e 175 v/s 178 has similar results whereby blood loss in both groups were comparable in both the studies with the difference being statistically not significant. ${ }^{10,12}$

Additional oxytocics were used when blood loss was more than usual. Women who were given misoprostol needed more additional oxytocic drugs in our study in comparison to methylergometrine group $4 \% \mathrm{v} / \mathrm{s}$ $2 \%, \mathrm{p}=0.585$ (Table 4). Injection prostodin $250 \mathrm{mcg}$ IM was used as additional oxytocic. Similiar study conducted by Amant et al concluded a higher requirement of oxytocics additionally in misoprostol group $12.8 \% \mathrm{v} / \mathrm{s}$ $4.4 \%$, whereas studies done by Refaey et al shows $14 \%$ $\mathrm{v} / \mathrm{s} 10 \%, \mathrm{p}=0.08$ and Walraven $\mathrm{G}$ et al showed $11 \%$ v/s12\%. ${ }^{7,10,12}$ The need for additional oxytocics were similar in both the study groups. However in none of these studies the difference was statistically not significant. None of the patients in both the study group required blood transfusion or surgical intervention.

Criteria for PPH were taken as blood loss measured $\geq 500 \mathrm{ml}$ in our study. $4 \%$ cases in Misoprostol group and $2 \%$ cases in Methyl ergometrine group had PPH whereas none of the patient had blood $\geq 1000 \mathrm{ml}$ (Table 4). In study conducted by F Amant et al, incidence of PPH was $8.3 \% \mathrm{v} / \mathrm{s} 4.3 \%$ and $1 \%$ had blood loss $\geq 1000 \mathrm{ml}^{7}$ Studies conducted by El-Rafaey et al $12 \%$ v/s $11 \%$ cases had blood loss $\geq 500 \mathrm{ml}$ and equal number of cases with blood loss $\geq 1000 \mathrm{ml}$ i.e $2 \%$. $^{10}$ In all the studies the incidence of PPH was not statistically significant.

In the present study, shivering was observed in $38 \%$ cases in misoprostol group compared to $8 \%$ cases in methylergometrine group which is statistically significant (Table 5). In the study conducted by F Amant et al the incidence of shivering in misoprostol and methylergometine group was $42 \% \mathrm{v} / \mathrm{s} 8.5 \%{ }^{7}$ Refaey et al has reported as high as $72 \% \mathrm{v} / \mathrm{s} 37 \%, \mathrm{p}<0.001$ incidence of shivering in misoprostol group. ${ }^{10}$ In the study conducted by Zachariah et al shivering was reported in misoprostol group compared to other oxytocics as $7.4 \%$, $2.1 \%, 3.7 \%{ }^{13}$ Although shivering is the major side-effect overall in all the studies, it is self-limiting and lasts for 20 -30mins. In some patients handling and feeding the neonate is problem which can be the reason for nonacceptance of misoprostol.

Pyrexia was observed in $4 \%$ in misoprostol group \& none of the cases in methylergometrine had pyrexia. H. EL. Refaey et al reported pyrexia $5 \% \mathrm{v} / \mathrm{s} 0.2 \%, \mathrm{p}<0.001 .^{10}$ Similarly Zachariah et al reported high incidence of pyrexia in misoprostol group compared to other oxytocics $6.7 \%, 0.7 \%, 2.0 \%$, whereas the study conducted by $\mathrm{F}$ Amant et al reported a significant high incidence of pyrexia in methylergometrine $34 \%$ as compared to $3 \%$ in misoprostol group. , $^{13}$ 
In the present study nausea was more common in methylergometrine group as compared to misoprostol group $18 \% \mathrm{v} / \mathrm{s} 6 \%$ (Table 5 ). In the study conducted by Amant et al the incidence of nausea in methylergometrine and misoprostol group was 30\% v/s $20 \%$. $^{7}$ Refaey et al reported $44 \% \mathrm{v} / \mathrm{s} 31 \%$ and Walraven $\mathrm{G}$ et al reported $2.3 \% \mathrm{v} / \mathrm{s} 0.9 \% .^{10,12}$ Vomitting was seen in $4 \% \mathrm{v} / \mathrm{s} 8 \%$ cases in misoprostol and methylergometrine group respectively. Amant et al reported the incidence of vomiting in methylergometine and misoprostol group $18 \% \mathrm{v} / \mathrm{s} 13 \%{ }^{7}$

Though diarrhoea has been considered as one of sideeffects of misoprostol, we did not have any cases of diarrhoea, as the patients were observed for the side effects only for 2 hrs. A study conducted by $\mathrm{P}$. Lumbiganon et al to know the side-effects of oral misoprostol during $24 \mathrm{hrs}$ after administration in third stage of labour found that diarrhoea usually starts after 1hour and subsides within $12 \mathrm{hrs}^{8}$

\section{CONCLUSION}

It is concluded from this study that both misoprostol and methylergometrine are equally effective in the active management of the $3^{\text {rd }}$ stage of labour in high risk cases. However, a comparison between two groups revealed that shivering and pyrexia were the commonest side effects with misoprostol and nausea was the most common side effect noted in methyl ergometrine, and the two drugs did not confer any significant advantage over the other in terms of duration of 3rd stage, blood loss during 3rd stage, and need for additional oxytocics or blood transfusion.

Although efficacy of both the drugs are comparable, even in presence of shivering which is a serious side effect but self-limiting with oral misoprostol offers several advantages over intravenous oxytocics like shelf-life of several years, stability at high temperatures (i.e., it does not require refrigeration) and oral administration i.e., it does not require needle or syringe which is a major advantage in the era of HIV and Hepatitis B. These advantages of misoprostol make it a feasible drug to be used in routine active management of the $3 \mathrm{rd}$ stage of labour especially in developing countries like ours, where $50-70 \%$ of deliveries take place at home, far from hospitals or medical facilities and are supervised solely by birth attendants.

\section{Funding: No funding sources} Conflict of interest: None declared

Ethical approval: The study was approved by the Institutional Ethics Committee

\section{REFERENCES}

1. Park K. Preventive and Social Medicine. $20^{\text {th }}$ Edn, Jabalpur, Banarsidas Bhanot Publishers. 2009:479481.

2. Prof Richard Derman J, Balchandra Kodkany S, Shivaprasad Goudar S, Stacie EG. Oral misoprostol in preventing postpartum haemorrhage in resource poor communities: a randomized controlled trail.The Lancet. 2006;368:1248-53.

3. Karmakar KS, Arup Kumar M, Chandana Das. Management options of postpartum hemorrhage An update. Obst \& Gynec Today. 2005;10(2):85.

4. El-Refaey H, O'Brien P, Morafa W, Walder J, Charles R. Misoprostol in $3^{\text {rd }}$ stage of labour. Lancet. 1996;347:1257.

5. El-Refaey H, O'Brien P, Morafa W, Walder J, Charles R. Use of oral misoprostol in the prevention of postpartum hemorrhage. Br J Obstet Gynecol. 1997;104:336-9.

6. Raghavan KS. Prostaglandins in labour. The management of labour, $1^{\text {st }}$ Edn. Chennai, Orient Longman. 1997:97-212.

7. Amant F, Bernard S, Timmerman D, Corremans A, Frans Andre VA. Misoprostol compared with methyl ergometrine for the prevention of postpartum hemorrhage: A double blind randomized trial. $\mathrm{Br} \mathrm{J}$ Obstet Gynecol. 1999;106:1066-70.

8. Lumbiganon P, Hofmeyr GJ, Gulmezoglu AM, Pinol A, Villar J. Misoprostol dose related shivering and pyrexia in the third stage of labour. $\mathrm{Br} \mathrm{J}$ Obstet Gynecol. 1999;106:304-8.

9. Spurrett B. Misoprostol and Human reproduction. Recent advances in Obstetrics and Gynaecology- 4. New Delhi, JPBMP. 1999:57-67.

10. El-Refaey H, Nooh R, O’Brien P, Abdalla M, Geary M, Walder J. The misoprostol third stage of labour study: A randomized controlled comparison between orally administered misoprostol and standard management. $\mathrm{Br} \quad \mathrm{J}$ Obstet Gynecol. 2000;107(9):1104-10.

11. Reddy R, Shenoy JV. Active management of third stage of labour. A comparative study in high-risk patients for atonic postpartum hemorrhage. J Obstet Gynecol Ind. 2001;51:44-7.

12. Walraven G, Blum J, Dampha Y, Sowe M, Morison $\mathrm{L}$, Beverly W. Misoprostol in the management of the third stage of labour in the home delivery setting in rural Gambia: a randomized controlled trial. $\mathrm{Br} \mathrm{J}$ Obstet Gynaec. 2005;112:1277-83.

13. Zachariah ES, Naidu M, Seshadri L. Oral misoprostol in the third stage of labour.Int $\mathrm{J}$ Obstet Gynaecol. 2006;92(1):23-6.

Cite this article as: Humera A, Kerure SB.

Randomized comparative study of oral misoprostol with intravenous methyl ergometrine in prevention of postpartum haemorrhage in cases high risk for postpartum haemorrhage. Int J Reprod Contracept Obstet Gynecol 2016;5:798-802. 